\title{
Understanding Consumer Stockpiling during the COVID-19 Outbreak through the Theory of Planned Behavior
}

\author{
Maria-Magdalena Roșu ${ }^{1, *}$, Rodica Ianole-Călin ${ }^{2}$, Raluca Dinescu ${ }^{2}$, Anca Bratu ${ }^{2}$, Răzvan-Mihail Papuc ${ }^{2}$ and \\ Anastasia Cosma $^{2}$ \\ 1 Faculty of Cybernetics, Statistics and Economic Informatics, Bucharest University of Economic Studies, \\ 010371 Bucharest, Romania \\ 2 Faculty of Business and Administration, University of Bucharest, 030018 Bucharest, Romania; \\ rodica.ianole@faa.unibuc.ro (R.I.-C.); raluca.dinescu@unibuc.ro (R.D.); anca.bratu@faa.unibuc.ro (A.B.); \\ razvanmihail.papuc@faa.unibuc.ro (R.-M.P.); anastasia.cosma@s.unibuc.ro (A.C.) \\ * Correspondence: rosumaria13@stud.ase.ro
}

check for

updates

Citation: Roșu, M.-M.; Ianole-Călin, R.; Dinescu, R.; Bratu, A.; Papuc, R.-M.; Cosma, A. Understanding Consumer Stockpiling during the COVID-19 Outbreak through the Theory of Planned Behavior. Mathematics 2021, 9, 1950. https://doi.org/10.3390/ math9161950

Academic Editor: Anatoliy Swishchuk

Received: 9 July 2021

Accepted: 9 August 2021

Published: 15 August 2021

Publisher's Note: MDPI stays neutral with regard to jurisdictional claims in published maps and institutional affiliations.

Copyright: (c) 2021 by the authors. Licensee MDPI, Basel, Switzerland. This article is an open access article distributed under the terms and conditions of the Creative Commons Attribution (CC BY) license (https:/ / creativecommons.org/licenses/by/ $4.0 /)$.

\begin{abstract}
We use the theory of planned behavior (TPB) to investigate determinants of stockpiling behavior during the COVID-19 lockdown. We analyzed 518 responses to an online survey and used Partial Least Squares Path Modeling (PLS-PM) techniques to estimate relationships between variables. Negative attitude (perceived barriers) and others' behavior (descriptive social norms) were revealed as significant predictors for both intention to over-purchase and the actual stockpiling behavior. The lack of significance obtained for perceived behavioral control (PBC) is also an important result, strengthening the evidence that factors' contribution to TPB's predictive power is strongly context-dependent, respectively that $\mathrm{PBC}$ is less relevant in settings dominated by uncertainty. The lack of significance is especially compelling when stockpiling behavior is regarded as deviant conduct from effective consumption. Our findings expand the understanding on the applicability of TPB and offer informed practical suggestions for improving managerial strategies, public and private ones, during extreme events when self-regulation and cognitive control are expedient but hard to achieve.
\end{abstract}

Keywords: theory of planned behavior; stockpiling behavior; panic buying; self-regulation; perceived product scarcity; COVID-19; lockdown

\section{Introduction}

The psychological impact of extreme events, either natural (e.g., earthquakes, hurricanes) or socioeconomic ones (e.g., 1979 oil crisis, 2007 financial crisis), is most commonly observed through behavior changes [1]. While for general cases, the amplitude and direction of changes are hard to predict, consumption patterns seem to be systematically pushed in the direction of over-purchasing, from quinine pursuit during the Spanish flu to the nowadays rush for utilitarian products, masks, and medicines [1,2].

The COVID-19 pandemic is the most recent event that has generated global panic buying for necessities. The peculiarity and the lack of preparedness for a novel disease caused notable global panic [3,4]. Psychological distress spiked in the early stages, from March to April 2020, and it has gradually returned to baseline by June 2020 [5], following the partial revival of the economic activity [6].

This immediate crisis reaction is equally relevant in developing and developed economies, but it is generated by different factors. In the former case, panic buying is a form of rational adaptation to disruptive phenomena such as hyperinflation [7], while in the latter one, the irrationality of panic buying derives from the absence of actual scarcity [1], being strongly impaired by emotions (e.g., threat perception, fear of the unknown, anxiety coping mechanisms, etc.) and social influences [8,9].

Individual scarcity cues (e.g., financial difficulties) and psychological inclinations (e.g., depression, neuroticism) play an enhancing role [1]. Similarly, herd mentality, documented 
for instance through information cascade effects (consumers within a network decide according to the behaviors and the choices of others [10]) is also known to impact consumer behaviors [2]. On the other hand, self-regulation and cognitive control were observed to reduce irrational behavior such as excessive food consumption [11-13] or compulsive buying [14].

Since COVID-19 is not only a health crisis but also an information crisis [15], disinformation, rumors, and sensationalism had a major impact on impulse buying $[2,9,16,17]$. The authors argue that even accurate, real-time information on COVID-19 provided not only the tools to make smart decisions but also a rationale for anxiety that may lead to panic buying [9]. The role of daily information was so crucial during COVID-19 lockdowns that some studies propose a complete chain-mediation between the daily perceived uncertainty on COVID-19 and daily impulsive buying [16,17].

The current study proposes a theory of planned behavior (TPB) approach to investigate the motives behind the panic buying observed in the beginning of the COVID-19 lockdown in Romania. The country case is relevant both from the perspective of specific post-communist patterns of consumption [18,19] and from the current ongoing market research measurements conducted during the pandemic. Namely, national statistics and other reports (i.e., Nielsen Romania) hint to an increase of roughly $40 \%$ in food sales in the early stages of pandemic (23 February-15 March 2020) compared to the same period 2019 [20], justifying the relevance of the context, which is in line with similar other international examples [21]. While there is a growing literature discussing the impact of COVID-19 on consumer behavior $[7,22]$ and some concrete examinations of panic buying correlates and antecedents $[23,24]$, there is almost no research conducted on the topic under the TPB framework (to date, we found only one such study [25]). Our analysis covers this gap, and it tackles both the intentional and the action side of this behavior based on a survey conducted in real time, thus minimizing the self-reported bias generated by subsequent over-purchasing behaviors in later stages of the pandemic. We illustrate that the variant of TPB with a higher specificity on the attitude and social norms variables has a strong predictive power, and it provides actionable insights for managerial and public communication strategies. Our findings reveal that barriers rather than benefits, respectively that others' behavior rather than their beliefs, impact individual conduct. The role of PBC appears strongly diminished in low controllability contexts such as panic buying, which is a finding that is further supported by the higher level of variance explained for the actual stockpiling behavior than the behavioral intention. Hence, the study contributes to a better understanding of consumer behavior in crisis situations and to the applicability of TPB in such highly unpredictable cases that require restraint and self-regulation.

The rest of the study is organized as follows. First, it offers a brief description of $\mathrm{TPB}$, together with the challenges derived from the contextual peculiarity (Section 2.1). Thereafter, we present our research model and hypotheses (Section 2.2), with methodological details provided in Section 3. Section 4 describes the results and we discussed them in Section 5, emphasizing theoretical and practical implications. Finally, conclusions, limitations, and future research directions are given in Section 6.

\section{Literature Review and Research Model}

\subsection{Theoretical Underpinning}

By approaching panic buying as deviant behavior from effective consumption, the current study tackles two major theoretical discussions: (1) the congruency between objectives and actual behavior and (2) the undermining factors behind intention and action.

A perfect match between intention and action implies a purely rational agent with calibrated expectations. Often, individuals do not follow plans toward healthy conducts or they exceed restraints from irrational habits. Behavioral science shows that restraint does not always meet an individual's intention to change [26,27] with a wide range of barriers, namely social, cognitive, or affective factors that impede the intention to restrict 
irrational behavior [28]. As mentioned before, effective conduct requires self-regulation and behavioral control [11-14].

The theory of planned behavior (TPB), an extension of the Theory of Reasoned Action (TRA) predicts both intention and action through attitude and subjective norms. Additionally, TPB proposes perceived behavioral control ( $\mathrm{PBC})$ as an additional behavior predictor and meta-analytic reviews on the model's performance conclude that TPB ex-plains roughly one-third of the variance in behavior and intention [29-31]. It is relevant to mention that PBC's influence in this variation is independent of attitude and subjective norms. Moreover, PBC seems to be a more powerful predictor than subjective norms [32], but it is dependent on individual beliefs about the presence or absence of resources and obstacles. Thus, there is an ongoing discussion of whether to consider the role of PBC only when one's perception of control and their actual control matches [33]. In the particular case of behaviors not being under complete volitional control, more technical arguments propose the employment of $\mathrm{PBC}$ as a moderator variable [34].

The scrutiny remains substantive for the analysis of consumer behaviors during the COVID-19 outbreak. By comparison to the research on preventive and safety measures, there are fewer studies on consumption. However, their number is constantly increasing, with interest in investigating the economic, psychological, and social implications of consumption patterns changes. Unsurprisingly, there is a rather high level of heterogeneity in terms of predictive power for considered factors of influence. The same applies to the factors scrutinized by the TPB model. Some authors argue that all three constructs-attitude, subjective norms, and PBC—significantly predicted social distancing intention [35,36]. Others concluded that attitude and subjective norms sustained social distancing, while the impact of $\mathrm{PBC}$ was rather insignificant in this time of uncertainty [33]. When considering traveling, $\mathrm{PBC}$ and attitude played a significant role, while subjective norms had a marginal influence on an individual's decision [37]. Scarcity cues, psychological distress, threat sensitivity, and mistrust of others accounted for around $35 \%$ of the variance in over-purchasing, and internal locus of control was positively associated with panic buying, in some samples [1]. Attitude and subjective norms strongly predicted over-purchasing, while PBC had the lowest impact on food panic buying [38]. The authors attribute this result to the perceived difficulty to conduct the behavior. Contrary to this finding, Barnes, Diaz, and Arnaboldi [39] argue that the lack of perceived control, driven by anxiety, leads to panic buying.

\subsection{Research Hypotheses}

Considering the debate on TPB applicability in uncertain times and the particular challenges of this endeavor, together with the contradicting findings on the factors leading to over-purchasing, the current study investigates stockpiling during COVID-19 lockdown through the lenses of TPB.

To investigate restraining behavior, we estimated two research models: one that predicts the respondents' intention to over-purchase, and the other one that predicts the respondents' actual stockpiling behavior. Both models share the same predictors driven by the TPB framework, as follows: attitudes toward adjusting consumption, perceived behavioral control to adjust consumption, and others stockpiling behavior as subjective norms.

A positive attitude toward adjusting consumption, namely considering the benefits of such an action, is linked to more creativity and improvisation in searching for solutions to address needs or in redefining them completely [40]. Such views act as effective framing for sharing and sustainable consumption, thus reducing panic buying.

The first hypothesis concerns the intention-action gap in case of restraint, while the following are based on TPB predictive factors.

Hypothesis 1 (H1). Actual stockpiling behavior exceeds the intention to adjust consumption.

Hypothesis 2 (H2). Attitude about effective consumption has a significant impact on stockpiling. 
Hypothesis 3 (H3). Attitude about effective consumption has a significant impact on the intention to over-purchase.

Hypothesis 4 (H4). Subjective norms have a significant impact on stockpiling.

Hypothesis 5 (H5). Subjective norms have a significant impact on the intention to over-purchase.

Hypothesis 6 (H6). Perceived behavioral control to adjust the level of consumption has a negative influence on stockpiling.

Hypothesis 7 (H7). Perceived behavioral control to adjust the level of consumption has a negative influence on the intention to over-purchase.

Some studies reveal that there is no significant difference concerning the fear of running out of food within demographic categories, except for the level of education [41], while others argue that individual's gender moderates such phenomenon with the effect being more pronounced among women [42]. Thus, we discussed how gender and age correlate with stockpiling and over-purchasing.

\section{Data, Materials and Methods}

\subsection{Questionnaire}

Data were collected through online questionnaires using convenience sampling $[43,44]$ and snowball sampling methods $[44,45]$. This approach leads to a large sample while also being cost-effective [46]. Previous studies on snowball sampling show large samples approach equilibrium independent of the convenience sample, even if the initial sample was non-random [44]. It is also important to mention that the pandemic context has reduced the gap between internet-based and offline populations considering that during lockdown, most activities shifted to work/study from home [47].

To capture the panic specific of the emerging virus outbreak, the online questionnaire was administered between 21 and 27 March 2020, two weeks after the lockdown began, via Facebook and Linkedin as an initial convenience sample of seeds [48]. The items of the survey covered the three categories of predictors proposed by the TPB-attitude, subjective norms, and perceived behavioral control.

To address the behavioral adjustment from an irrational practice, we measured the intention to buy more and the actual stockpiling behavior together with the assessment of attitude and perceived behavior control toward effective consumption. To capture herd mentality, shown to impact consumer behaviors, we measure subjective norms regarding stockpiling behavior [10].

We approached the predictors through multiple components as suggested by previous research $[49,50]$. The research on the TPB model's reliability recommends that the attitude toward a specific behavior be composed of instrumental (rewarding or demanding) and affective (enjoyable or unpleasant) evaluations of the respective behavior [49,51]. For our analysis, we solely considered the instrumental attitude. To this end, we assessed perceived barriers (general effort and psychological distress) and perceived benefits (economic and personal) of effective consumption. The items measuring attitude were as follows:

- $\quad$ BAR1: Adjusting your current consumption behavior to your actual needs requires significant effort (objective barrier).

- BAR2: The prospect of adjusting your consumption level scares you (psychological distress).

- $\quad$ BEN1: The prospect of adjusting your current consumption level helps you understand what your actual needs are (personal benefit).

- $\quad$ BEN2: The prospect of adjusting your current consumption level helps you from an economic point of view (economic benefit). 
Rather than viewing subjective norms as a unitary construct, some authors argue that social norms separately reflect conceptions of what others approve of (injunctive norms) and what others do (descriptive norms [50,52]). Additionally, social pressure manifests through social identity. The group identification approach considers the impact of group membership on behavior: social norms are more convincing if tied to salient groups $[50,53,54]$. These considered, for the measurement of injunctive norms, the items were as follows:

- IN1: Your friends find that scarcity of basic products is very likely to appear.

- IN2: Your family finds that scarcity of basic products is very likely to appear.

- IN3: People find that scarcity of basic products is very likely to appear.

For the measurement of descriptive norms, we proposed:

- DN1: You have friends/acquaintances who tend to stock up trying to manage a possible scarcity of basic products.

- DN2: Members of your family tend to stock up trying to manage a possible scarcity of basic products.

Perceived behavioral control, intention, and actual behavior were measured as proposed by Rhodes and Courneya [49]. Perceived behavioral control was interrogated as an assessment of self-efficacy:

- $\quad$ PBC: You feel perfectly able to adjust your consumption level to your actual needs during this period of time.

Behavioral intention to buy more was measured by referring to future actions, and actual stockpiling behavior was surveyed by mentioning current actions:

- BI: Next time when you shop for basic products, you will buy more than usual.

- $\mathrm{AB}$ : These days, you tend to stockpile trying to manage a possible scarcity of basic products.

We measured the respondents' level of agreement on a 1-7 scale. In addition, we included an open question to identify the type of products that were perceived as scarce at the time of measurement: "What are, if the case, the products that you may need, but that are not available anymore?" The survey also recorded demographics and socioeconomic variables (i.e., age, gender, level of education, income, and civil status).

Consequently, the hypotheses proposed in the introduction, elaborated around the predictors' components, are as follows (summarized in Figure 1):

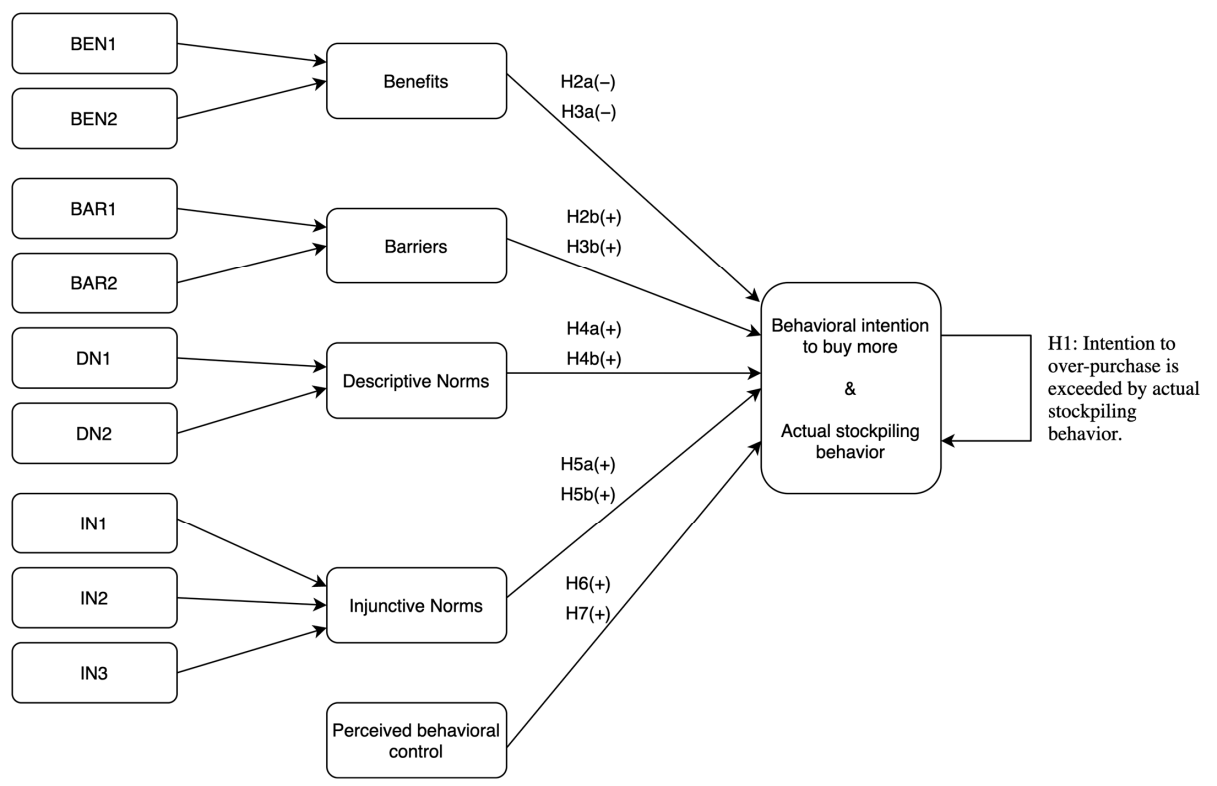

Figure 1. Research hypotheses. 
Hypothesis 1 (H1). Actual stockpiling behavior exceeds the intention to adjust consumption.

Hypothesis 2a (H2a). Benefits of effective consumption have a negative influence on stockpiling.

Hypothesis $\mathbf{2 b}(\mathbf{H} \mathbf{2 b})$. Barriers to adjusting consumption have a positive influence on stockpiling.

Hypothesis 3a (H3a). Benefits of effective consumption have a negative influence on the intention to over-purchase.

Hypothesis $\mathbf{3 b} \mathbf{( H 3 b ) . ~ B a r r i e r s ~ t o ~ a d j u s t i n g ~ c o n s u m p t i o n ~ h a v e ~ a ~ p o s i t i v e ~ i n f l u e n c e ~ o n ~ t h e ~ i n t e n t i o n ~}$ to over-purchase.

Hypothesis 4a (H4a). Other people's panic buying behavior has a positive influence on stockpiling.

Hypothesis $4 \mathbf{b} \mathbf{( H 4 b ) . ~ O t h e r ~ p e o p l e ' s ~ b e l i e f s ~ r e g a r d i n g ~ f o o d ~ p a n i c ~ b u y i n g ~ h a v e ~ a ~ p o s i t i v e ~ i n f l u e n c e ~}$ on stockpiling.

Hypothesis 5a (H5a). Other people's panic buying behavior has a positive influence on the intention to buy more.

Hypothesis $\mathbf{5 b} \mathbf{( H 5 b ) . ~ O t h e r ~ p e o p l e ' s ~ b e l i e f s ~ r e g a r d i n g ~ f o o d ~ p a n i c ~ b u y i n g ~ h a v e ~ a ~ p o s i t i v e ~ i n f l u e n c e ~}$ on the intention to over-purchase.

Hypothesis 6 (H6). Perceived behavioral control to adjust the level of consumption has a negative influence on stockpiling.

Hypothesis 7 (H7). Perceived behavioral control to adjust the level of consumption has a negative influence on the intention to over-purchase.

\subsection{Data}

Our sample comprises 518 respondents, aged 15-82 $($ mean $=30.24$, median $=24)$, out of which $73 \%$ were women. Table 1 presents the descriptive statistics.

Table 1. Demographics and socioeconomic variables.

\begin{tabular}{cc}
\hline Variable & Statistics \\
\hline Age & Min =15, Max = 82, Mean = 30.24 (sd = 12.85) \\
\hline Gender: & $73 \%$ \\
Female & $26 \%$ \\
Male & $1 \%$ \\
No response & \\
\hline The highest level of completed education: & $45 \%$ \\
Middle education & $55 \%$ \\
Higher education & \\
Your income is: & $21 \%$ \\
Less than my daily needs & $62 \%$ \\
Enough for my daily needs & $17 \%$ \\
Above my daily needs & \\
Your civil status is: & $33 \%$ \\
Single & $37 \%$ \\
In a relationship & $30 \%$ \\
Married &
\end{tabular}




\subsection{Method}

Given the significant departure of our variables from normality, we rely on a PLS-PM technique to estimate both models. For exploratory studies with a relatively large number of indicators or construct variables, including potential multicollinearity issues [55], PLS-PM is also preferred to other similar modeling approaches, such as the COV-SEM technique [56]. This analysis captures both the relationship between the constructs and their composing indicators (the external/measurement model) and the relationship between latent variables (the internal model $[55,57])$. We conducted our data analysis using WarpPLS statistical analysis software, version 6.0 (Laredo, TX, USA).

\section{Results}

\subsection{Qualitative Results}

In order to obtain more details about the necessary products that people did not find in stores in the early stage of the lockdown, we asked participants to respond to the following open-ended question: "What are, if the case, the products that you may need, but that are not available anymore?".

Generally, the responses emphasize two dominant types of unavailable products: staple foods and medicines. More specifically, we grouped them into the following categories: (1) Basic foods and non-alcoholic beverages; (2) Medical supplies (medicines, masks, disinfectant, protective equipment, alcohol); (3) No perceived product scarcity; (4) Non-perishable basic products (detergents, paper); (5) Other non-perishable products (cosmetics); (6) Various other foods (pastries, frozen products); (7) Alcoholic beverages. Figure 2 shows the percentages associated with each category.

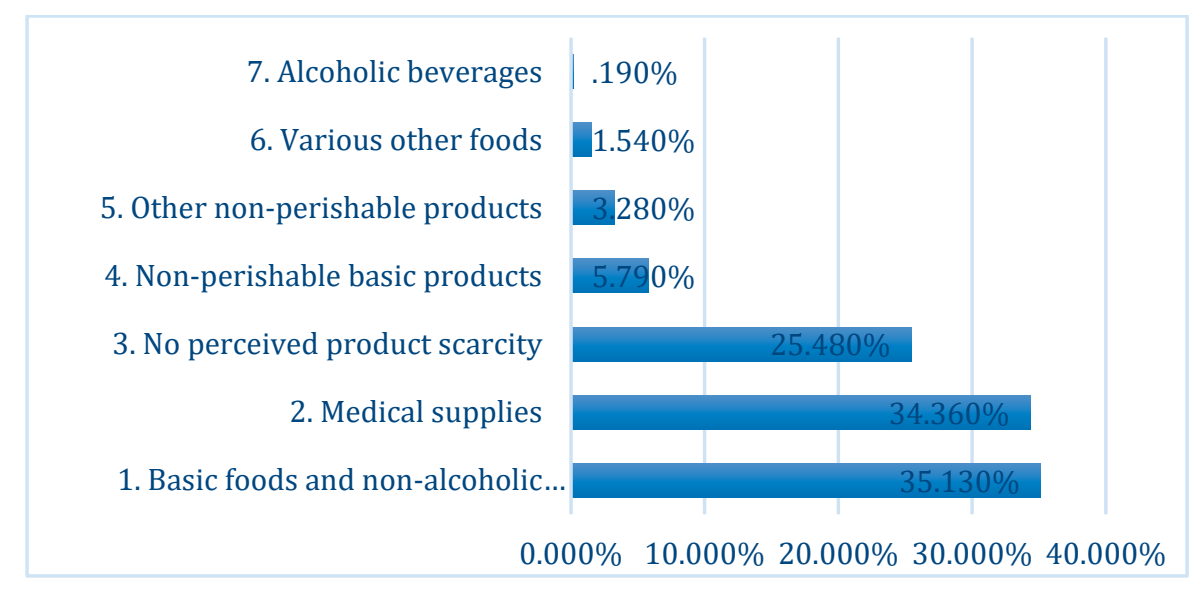

Figure 2. Perceived product scarcity (exploratory categories).

The third ranked category, composed of approximately $25 \%$ of the participants, includes no perceived product scarcity, thus those that indicated not to encounter any type of product scarcity. We may postulate that they have made a completely different risk assessment [58] than the rest of the sample, exhibiting an opposite behavior to panic buying, specific to a rational customer. It is noteworthy that $85 \%$ of these 132 respondents come from urban areas. Thus, we may associate the answers with their proximity to a higher number of basic food shopping points. In a similar vein, most respondents of this group $(65 \%)$ answered that they have sufficient income for daily needs.

Lastly, $7.33 \%$ of the participants declined to answer the open-ended question or have chosen the "I don't know" option.

\subsection{Reliability and Validity of the Measurement Model}

Table 2 summarizes the results of the reliability and robustness of the measurement model. The values of the Composite Reliability indicator range between 0.869 (Benefits) to 0.913 (Injunctive Norms), thus exceeding the recommended thresholds [55]. The Cronbach's 
alpha values, measuring the internal consistency of the items, are higher than 0.7 with one exception (Benefits) for which the value is slightly below this threshold. However, a small departure is usually accepted in exploratory studies and for a small number of scale items [59-61]. Discrepancies between the Composite Reliability Indicator and Cronbach's alpha are not uncommon, with the latter being considered less robust to varying factor loadings of the items, thus underestimating the true reliability [54,62]. The Average Variance Extracted shows adequate, above 0.5 values [57], so it proves the reliability of our measurement. In addition to the models' fit indices, all factor loadings for each observed variable are higher than 0.7 , indicating that the majority of variance in these variables is explained by the construct to which they are related [63].

Table 3 shows the results of the discriminant validity check. The diagonal values are all above 0.8 , the threshold imposed by the existing literature, while all off-diagonal values are lower than the corresponding diagonal values [34]. Additionally, the shared variance (squared correlations) between every two constructs is smaller than all constructs' AVE presented in Table 2 [63]. These results show good discriminant validity of our constructs.

Table 4 shows the combined loadings and cross-loadings for all latent constructs. The recommended threshold for loadings is 0.7 and, as noted in the table, the values range from 0.854 to 0.904 . In addition, all non-diagonal values are lower than the diagonal values, all evidence showing good convergent validity.

Table 2. Assessment of the measurement model is a table.

\begin{tabular}{|c|c|c|c|c|c|}
\hline Variable & $\begin{array}{l}\text { Composite Reliability } \\
\text { (Dillon Goldstein Rho) }\end{array}$ & Cronbach's Alpha & $\begin{array}{l}\text { Average Variance } \\
\text { Extracted (AVE) }\end{array}$ & $\begin{array}{l}\text { Observed } \\
\text { Variable }\end{array}$ & Loadings \\
\hline Benefits & 0.869 & 0.698 & 0.768 & $\begin{array}{l}\text { BEN1 } \\
\text { BEN22 }\end{array}$ & $\begin{array}{l}0.876 \\
0.876\end{array}$ \\
\hline Barriers & 0.874 & 0.712 & 0.776 & $\begin{array}{l}\text { BAR1 } \\
\text { BAR2 }\end{array}$ & $\begin{array}{l}0.881 \\
0.881\end{array}$ \\
\hline Descriptive Norms & 0.900 & 0.777 & 0.818 & $\begin{array}{l}\text { DN1 } \\
\text { DN2 }\end{array}$ & $\begin{array}{l}0.904 \\
0.904\end{array}$ \\
\hline Injunctive Norms & 0.913 & 0.857 & 0.778 & $\begin{array}{l}\text { IN1 } \\
\text { IN2 } \\
\text { IN3 }\end{array}$ & $\begin{array}{l}0.897 \\
0.893 \\
0.854\end{array}$ \\
\hline
\end{tabular}

Table 3. Discriminant validity (inter-correlations) of latent constructs.

\begin{tabular}{ccccc}
\hline Variable & Benefits & Barriers & Descriptive Norms & Injunctive Norms \\
\hline Benefits & 0.876 & 0.108 & 0.202 & 0.266 \\
Barriers & & 0.881 & 0.342 & 0.232 \\
Descriptive Norms & & & 0.904 & 0.522 \\
Injunctive Norms & & & 0.882 \\
\hline
\end{tabular}

Table 4. Convergent validity (inter-correlations) of variable constructs.

\begin{tabular}{ccccc}
\hline Variable & Benefits & Barriers & Descriptive Norms & Injunctive Norms \\
\hline BEN1 & 0.876 & 0.047 & 0.130 & 0.021 \\
BEN2 & 0.876 & -0.047 & -0.130 & -0.021 \\
BAR1 & -0.081 & 0.881 & 0.140 & 0.047 \\
BAR2 & 0.081 & 0.881 & -0.140 & -0.047 \\
DN1 & 0.060 & -0.026 & 0.904 & -0.010 \\
DN2 & -0.060 & 0.026 & 0.904 & 0.010 \\
IN1 & 0.057 & -0.019 & -0.006 & 0.897 \\
IN2 & 0.007 & -0.011 & -0.073 & 0.893 \\
IN3 & -0.067 & 0.032 & 0.083 & 0.854 \\
\hline
\end{tabular}


Theorem-type environments (including propositions, lemmas, corollaries, etc.) can be formatted as follows:

\subsection{The PLS Models}

Table 5 shows the results of the two PLS models: the model predicting intention to buy more and the model predicting actual stockpiling behavior. Results reveal that the "Barriers" and "Descriptive Norms" variables are statistically significant. Age, education, income, and gender show no significant impact on intention or actual behavior. Both models have good explanatory power, and the variations of the actual behavior are better explained $(67.4 \%)$ than the variations in the intended behavior (36.5\%). For both models, the overall model fit, underlined by the standardized root mean square residual (SRMR), is well within the acceptable level (SRMR $<0.08$ shows a very good fit [64]). The Tenehaus $\mathrm{GoF}$ (goodness of fit) is better for the former model (0.753) than for the latter model (0.593).

Table 5. The results of the PLS models.

\begin{tabular}{|c|c|c|}
\hline Model & Actual Stockpiling Behavior & $\begin{array}{c}\text { Behavioral Intention to Buy } \\
\text { More }\end{array}$ \\
\hline \multicolumn{3}{|l|}{ Estimated coefficients } \\
\hline Benefits & $\begin{array}{c}0.047 \\
(0.223)\end{array}$ & $\begin{array}{c}0.064 \\
(0.147)\end{array}$ \\
\hline Barriers & $\begin{array}{l}0.231 * * * \\
(<0.001)\end{array}$ & $\begin{array}{l}0.296 * * * \\
(<0.001)\end{array}$ \\
\hline Descriptive Norms & $\begin{array}{l}0.674^{* * *} \\
(<0.001)\end{array}$ & $\begin{array}{l}0.365^{* * *} \\
(<0.001)\end{array}$ \\
\hline Injunctive Norms & $\begin{array}{c}0.002 \\
(0.486)\end{array}$ & $\begin{array}{c}0.063 \\
(0.152)\end{array}$ \\
\hline PBC & $\begin{array}{c}0.054 \\
(0.187)\end{array}$ & $\begin{array}{l}-0.039 \\
(0.262)\end{array}$ \\
\hline Age & $\begin{array}{c}0.001 \\
(0.495)\end{array}$ & $\begin{array}{l}-0.059 \\
(0.169)\end{array}$ \\
\hline $\begin{array}{l}\text { Gender } \\
\text { Male } \\
\text { Female }\end{array}$ & $\begin{array}{c}\text { Reference } \\
-0.032 \\
(0.303)\end{array}$ & $\begin{array}{c}\text { Reference } \\
-0.064 \\
(0.147)\end{array}$ \\
\hline $\begin{array}{l}\text { Income } \\
\text { Above my daily needs } \\
\text { Enough for my daily needs } \\
\text { Less than my daily needs }\end{array}$ & $\begin{array}{c}\text { Reference } \\
-0.003 \\
(0.922)\end{array}$ & $\begin{array}{c}\text { Reference } \\
0.005 \\
(0.894)\end{array}$ \\
\hline $\begin{array}{l}\text { Education } \\
\text { Higher education } \\
\text { Middle education }\end{array}$ & $\begin{array}{c}\text { Reference } \\
0.017 \\
(0.550)\end{array}$ & $\begin{array}{c}\text { Reference } \\
0.011 \\
(0.811)\end{array}$ \\
\hline \multicolumn{3}{|l|}{ Goodness of fit measures } \\
\hline R2/Adjusted 2 & $63.6 \%$ & $39.5 \%$ \\
\hline $\begin{array}{c}\text { Tenehaus GoF } \\
(\text { small } \geq 0.1, \text { medium } \geq 0.25, \\
\text { large } \geq 0.36)\end{array}$ & 0.753 & 0.593 \\
\hline SRMR & 0.07 & 0.068 \\
\hline SMAR & 0.05 & 0.048 \\
\hline
\end{tabular}

Note: $p$-values in parentheses; ${ }^{* * *}-p$-value $<0.001$.

Table 6 presents the effect size for each TPB predictor. The effect sizes underline the strength of a relationship between variables and, consequently, the effectiveness of an intervention on that relationship. The effect size must show values greater than 0.02 [65]. Both "Barriers" and "Descriptive Norms" variables reveal large effect sizes when predicting the behavioral intention and the actual stockpiling behavior. By far, the "Descriptive Norms" variable displays the largest effect size, first concerning the predicted intention and 
subsequently the actual stockpiling behavior. "Injunctive Norms" indicates considerable effect size, but the variable is not revealed as significant for the PLS models.

Table 6. Effect sizes—both models.

\begin{tabular}{ccc}
\hline Model & $\begin{array}{c}\text { Behavioral Intention to Buy } \\
\text { More }\end{array}$ & Actual Stockpiling Behavior \\
\hline Effect sizes of the predictors & & 0.014 \\
\hline Attitudes-Benefits & 0.012 & 0.140 \\
Attitudes-Barriers & 0.111 & 0.193 \\
Descriptive Norms & 0.521 & 0.023 \\
Injunctive Norms & 0.001 & 0.009 \\
\hline
\end{tabular}

\section{Discussion}

Our study offers an informed perspective of how panic buying was experienced in Romania. The qualitative insights confirm that people have over-purchased mostly basic foods $(35.13 \%)$ and medical supplies (34.36\%) since the lockdown announcement, responding to the alarming media titles of the period (e.g., "Hunger will kill us" [66], "Food crisis hits Romania" [67]).

\subsection{Theoretical Implications}

The quantitative analysis revealed a strong predictive power of TPB models both for respondents' intention to over-purchase (39.5\% variance explained) and the actual stockpiling behavior (63.6\% variance explained). We attribute the above-average predictability to the specificity of predictors' measurement, which was an approach previously suggested by Montano and Kasprzyk [68]. In this sense, we decomposed attitude measurement into positive attitude (benefits) and negative attitude (barriers). Only barriers revealed significance in determining intention and behavior, which is consistent with existing studies on the impact of perceived benefits and barriers on professional success [69] and health behavior [70]. Similarly, we deconstructed subjective norms into other people's beliefs and other people's behavior. Results solely underline the impact of other people's behavior on individual decision making. We can interpret this finding with the argument of White et al. [50] that descriptive norms describe more convincingly the typical behavior acceptable within a community. The distinction between types of attitude and types of social influence had the potential to eliminate noise and, thus, more accurately predict intention and behavior. The higher level of variance explained for the actual stockpiling behavior by comparison to behavioral intention may be attributed to the rapid consumer responses to perceived scarcity, such as heightened arousal [71] or mere urgency effect [72], fastening the route to action, with less involvement and premeditated intention on the buying decisions [73]. In addition, we contribute to the prolific debate on the applicability and proper conceptualization of the PBC in predicting behaviors seen as low in controllability, aligning our work to the argument that the impact of $\mathrm{PBC}$ is rather marginal in panic buying settings. The validation of TPB in a restraint setting where the predictors express the desirable behavior and the intention/action refers to the behavior that ideally should be restricted is another noteworthy contribution.

\subsection{Practical Implications}

The effect sizes illustrating a strong relationship between barriers and intention/behavior, respectively between other people's behavior and intention/behavior, offer a solid ground for practical implications. On the barriers' side of adjusting consumption, we find concerns related to the effort involved and fear associated with the process. These factors mirror to a certain extent the stressors usually cited in resistance to change interventions [74], and they could be an important ingredient of new managerial strategies in the challenged area of supply and warehouse operations. Specifically, next to much needed online procurement procedures [7], the stores could also address the above factors by creating spaces for consumers to update 
and reflect on shopping lists and to further invest in applications that are easy to follow and trustworthy in terms of product availability, payment, and delivery security [75]. These insights follow the recommendations to reduce perceived stress, as documented in a recent study conducted in Poland [24]. From a public communication perspective, diminishing the impact of barriers could be obtained by consistently informing people that panic buying is a sporadic phenomenon (up to 7-10 days) and by not resuming public action to simplistic and inefficient messages such as "don't panic" [76].

Interventions emphasizing how other people behave are much harder to instrument, especially since the items refer to family and friends. However, this insight is still valuable in the sense of observing just a very small effect size for injunctive norms, supporting an eventual shift of resources toward actions visible in smaller communities [77,78]. Similarly, as a result of no impact obtained for $\mathrm{PBC}$, public campaigns should insist less on the internal locus of control and rather emphasize the external one. This could be achieved by strengthening trust in experts and government actions, as it was previously proved for the case of natural disasters or other crisis situations $[8,79]$.

\section{Conclusions, Limitations, and Future Research}

The COVID-19 pandemic contrived and exposed a diverse set of unusual economic behaviors, similar to those previously observed in the case of other extreme events. One rampant dimension of consumption practices was the stockpiling tendency materialized at the beginning of the pandemic, raising questions about the underlying factors leading to over-purchasing $[1,2,10]$ and the effective measures for reducing irrational behavior during such critical times [9]. Our study serves these objectives by looking at the individual instances determining stockpiling intention and behavior, while isolating the uncertainty factor through the PBC construct. The results show that the traditional TPB model continues to be a relevant theoretical framework for investigating behavior changes. However, it also suggests that highly uncertain circumstances require special attention in terms of model conceptualization.

Indeed, our results reveal that attitude and subjective norms significantly affected stockpiling intention/behavior during the COVID-19 pandemic. Specifically, more scrutiny into the nature of these variables shows that perceived barriers rather than perceived benefits, respectively descriptive norms rather than injunctive norms, are the actual relevant determinants. Similar investigations underline the predictive role of attitude and subjective norms for stockpiling behavior in Germany [25] and Poland [24]. The null result obtained for the $\mathrm{PBC}$ invites future studies to decide on a potential explanation: the perceived difficulty to conduct behavior in uncertain times [38] or the impact of disinformation in a period of information abundance $[2,9,16,17]$.

The questions addressed in our survey were formulated in such a manner that they would tackle basic behaviors without encompassing respondents' specific preferences relevant to cultural comparison (i.e., recognized food preferences: health-conscious, heavy drinkers, etc. [80], individualism-collectivism orientation [81]). Nonetheless, future work may consider cultural particularities as potential moderators of stockpiling behaviors in crisis situations. This is especially important considering the weak cross-cultural research on panic buying, respectively the lack of evidence for areas such as South America, Russia, Africa, and Scandinavia [82].

Lastly, there are several limitations associated with this study. First, due to limited time resources and the lockdown itself, data were collected through the online survey method, and our sample is not representative of both urban and rural areas in Romania. However, this was the only feasible option of conducting research in real time during the most acute stages of the pandemic. More so, Romania presents the advantage of one of the best high-speed internet infrastructures in Europe and wide internet access [83]. It would be ideal if future research would examine similar questions on a more comprehensive sample, carefully accounting for different potential biases interfering with the recent memories of the lockdown. Complementing the survey with experimental methods could also be 
helpful. Second, while our models present robust metrics of performance, it is important to consider other relevant variables that might impact behavioral outcomes (psychological traits, social media use, etc.).

Author Contributions: Conceptualization, M.-M.R. and R.I.-C.; methodology, M.-M.R. and R.I.-C.; software, M.-M.R. and R.D.; validation, A.C.; formal analysis, R.I.-C. and R.D.; investigation, M.-M.R., A.B. and R.D.; resources, A.C. and R.-M.P.; data curation, A.C.; writing-original draft preparation, M.-M.R., R.I.-C. and R.D.; writing—review and editing, A.B., R.-M.P. and A.C.; visualization, R.D.; supervision, R.I-C. All authors have read and agreed to the published version of the manuscript.

Funding: This research received no external funding.

Institutional Review Board Statement: Ethical review and approval were waived for this study due to voluntary online participation with the possibility of withdrawal and the use of non-identifiable data.

Informed Consent Statement: Informed consent was obtained from all subjects involved in the study.

Data Availability Statement: Data are available on request.

Acknowledgments: We thank Elena Druică for her feedback and support in conducting this research.

Conflicts of Interest: The authors declare no conflict of interest.

\section{References}

1. Bentall, R.P.; Lloyd, A.; Bennett, K.; McKay, R.; Mason, L.; Murphy, J.; McBride, O.; Hartman, T.K.; Gibson-Miller, J.; Levita, L.; et al. Pandemic Buying: Testing a Psychological Model of over-Purchasing and Panic Buying Using Data from the United Kingdom and the Republic of Ireland during the Early Phase of the COVID-19 Pandemic. PLoS ONE 2021, 16, e0246339. [CrossRef]

2. Loxton, M.; Truskett, R.; Scarf, B.; Sindone, L.; Baldry, G.; Zhao, Y. Consumer Behaviour during Crises: Preliminary Research on How Coronavirus Has Manifested Consumer Panic Buying, Herd Mentality, Changing Discretionary Spending and the Role of the Media in Influencing Behaviour. J. Risk Financ. Manag. 2020, 13, 166. [CrossRef]

3. Freimuth, V.; Linnan, H.W.; Potter, P. Communicating the Threat of Emerging Infections to the Public. Emerg. Infect. Dis. 2000, 6, 337. [CrossRef]

4. Costa, K. The Cause of Panic at the Outbreak of COVID-19 in South Africa-a Comparative Analysis with Similar Outbreak in China and New York. SSRN 2020. [CrossRef]

5. Daly, M.; Robinson, E. Psychological Distress and Adaptation to the COVID-19 Crisis in the United States. J. Psychiatr. Res. 2021, 136, 603-609. [CrossRef]

6. Droste, M.; Stock, J.H. Adapting to the COVID-19 Pandemic. AEA Papers Proc. 2021, 111, 351-355. [CrossRef]

7. Sheth, J. Impact of Covid-19 on Consumer Behavior: Will the Old Habits Return or Die? J. Bus. Res. 2020, 117, 280-283. [CrossRef]

8. Yuen, K.F.; Wang, X.; Ma, F.; Li, K.X. The Psychological Causes of Panic Buying Following a Health Crisis. Int. J. Environ. Res. Public Health 2020, 17, 3513. [CrossRef] [PubMed]

9. Naeem, M. Do Social Media Platforms Develop Consumer Panic Buying during the Fear of Covid-19 Pandemic. J. Retail. Consum. Serv. 2021, 58, 102226. [CrossRef]

10. Easley, D.; Kleinberg, J. Networks, Crowds, and Markets; Cambridge University Press: Cambridge, MA, USA, 2010 ; Volume 8.

11. Larsen, J.K.; van Strien, T.; Eisinga, R.; Herman, C.P.; Engels, R.C. Dietary Restraint: Intention versus Behavior to Restrict Food Intake. Appetite 2007, 49, 100-108. [CrossRef] [PubMed]

12. Johnson, F.; Pratt, M.; Wardle, J. Dietary Restraint and Self-Regulation in Eating Behavior. Int. J. Obes. 2012, 36, 665-674. [CrossRef]

13. Dochat, C.; Godfrey, K.M.; Golshan, S.; Cuneo, J.G.; Afari, N. Dietary Restraint and Weight Loss in Relation to Disinhibited Eating in Obese Veterans Following a Behavioral Weight Loss Intervention. Appetite 2019, 140, 98-104. [CrossRef] [PubMed]

14. Sohn, S.-H.; Choi, Y.-J. A Model of Compulsive Buying: Dysfunctional Beliefs and Self-Regulation of Compulsive Buyers. Soc. Behav. Personal. Int. J. 2012, 40, 1611-1624. [CrossRef]

15. Xie, B.; He, D.; Mercer, T.; Wang, Y.; Wu, D.; Fleischmann, K.R.; Zhang, Y.; Yoder, L.H.; Stephens, K.K.; Mackert, M.; et al. Global Health Crises Are Also Information Crises: A Call to Action. J. Assoc. Inf. Sci. Technol. 2020, 71, 1419-1423. [CrossRef] [PubMed]

16. Ahmed, R.R.; Streimikiene, D.; Rolle, J.-A.; Pham, A.D. The COVID-19 Pandemic and the Antecedants for the Impulse Buying Behavior of US Citizens. J. Compet. 2020, 12, 5-27. [CrossRef]

17. Xiao, H.; Zhang, Z.; Zhang, L. A Diary Study of Impulsive Buying during the COVID-19 Pandemic. Curr. Psychol. 2020, 1-13. [CrossRef]

18. Kreidl, M. Perceptions of Poverty and Wealth in Western and Post-Communist Countries. Soc. Justice Res. 2000, 13, 151-176. [CrossRef]

19. Ianole, R.; Cornescu, V. Overconsumption Society through the Looking-Glass of Behavioral Economics. Procedia Econ. Financ. 2013, 6, 66-72. [CrossRef]

20. Stanciu, M.; Mihăilescu, A.; Humă, C. Stare de Urgență Pentru Consumul Populatiei-Recurs La Reflecție Asupra Trebuințelor Esențiale; Institutul de Cercetare a Calității Vieții: București, Romania, 2020. 
21. Yang, Y.; Li, O.; Peng, X.; Wang, L. Consumption Trends During the COVID-19 Crisis: How Awe, Coping, and Social Norms Drive Utilitarian Purchases. Front. Psychol. 2020, 11, 588580. [CrossRef]

22. Cambefort, M. How the COVID-19 Pandemic Is Challenging Consumption. Mark. Glob. Dev. Rev. 2020, 5. [CrossRef]

23. Islam, T.; Pitafi, A.H.; Arya, V.; Wang, Y.; Akhtar, N.; Mubarik, S.; Xiaobei, L. Panic Buying in the COVID-19 Pandemic: A Multi-Country Examination. J. Retail. Consum. Serv. 2021, 59, 102357. [CrossRef]

24. Jeżewska-Zychowicz, M.; Plichta, M.; Królak, M. Consumers' Fears Regarding Food Availability and Purchasing Behaviors during the COVID-19 Pandemic: The Importance of Trust and Perceived Stress. Nutrients 2020, 12, 2852. [CrossRef]

25. Lehberger, M.; Kleih, A.-K.; Sparke, K. Panic Buying in Times of Coronavirus (COVID-19): Extending the Theory of Planned Behavior to Understand the Stockpiling of Nonperishable Food in Germany. Appetite 2021, 161, 105118. [CrossRef]

26. Ianole, R. Applied Behavioral Economics Research and Trends; IGI Global: Hershey, PA, USA, 2016; ISBN 1-5225-1827-4.

27. Schwarzer, R. Modeling Health Behavior Change: How to Predict and Modify the Adoption and Maintenance of Health Behaviors. Appl. Psychol. 2008, 57, 1-29. [CrossRef]

28. Bublitz, M.G.; Peracchio, L.A.; Block, L.G. Why Did I Eat That? Perspectives on Food Decision Making and Dietary Restraint. J. Consum. Psychol. 2010, 20, 239-258. [CrossRef]

29. Armitage, C.J.; Conner, M. Efficacy of the Theory of Planned Behaviour: A Meta-Analytic Review. Br. J. Soc. Psychol. 2001, 40, 471-499. [CrossRef]

30. Hagger, M.; Chatzisarantis, N.L.D.; Biddle, S.J.H. A Meta-Analytic Review of the Theories of Reasoned Action and Planned Behavior in Physical Activity: Predictive Validity and the Contribution of Additional Variables. J. Sport Exerc. Psychol. 2002, 24, 3-32. [CrossRef]

31. Trafimow, D.; Sheeran, P.; Conner, M.; Finlay, K.A. Evidence That Perceived Behavioural Control Is a Multidimensional Construct: Perceived Control and Perceived Difficulty. Br. J. Soc. Psychol. 2002, 41, 101-121. [CrossRef] [PubMed]

32. Madden, T.J.; Ellen, P.S.; Ajzen, I.A. Comparison of the Theory of Planned Behavior and the Theory of Reasoned Action. Personal. Soc. Psychol. Bull. 1992, 18, 3-9. [CrossRef]

33. Das, A.K.; Abdul Kader Jilani, M.M.; Uddin, M.S.; Uddin, M.A.; Ghosh, A.K. Fighting Ahead: Adoption of Social Distancing in COVID-19 Outbreak through the Lens of Theory of Planned Behavior. J. Hum. Behav. Soc. Environ. 2021, 31, 373-393. [CrossRef]

34. Baron, R.M.; Kenny, D.A. The Moderator-Mediator Variable Distinction in Social Psychological Research: Conceptual, Strategic, and Statistical Consider-Ations. J. Personal. Soc. Psychol. 1986, 51, 1173-1182. [CrossRef]

35. Farias, J.E.M.; Pilati, R. Violating Social Distancing amid COVID-19 Pandemic: Psychological Factors to Improve Compliance. PsyArXiv 2020. [CrossRef]

36. Andarge, E.; Fikadu, T.; Temesgen, R.; Shegaze, M.; Feleke, T.; Haile, F.; Endashaw, G.; Boti, N.; Bekele, A.; Glagn, M. Intention and Practice on Personal Preventive Measures Against the COVID-19 Pandemic Among Adults with Chronic Conditions in Southern Ethiopia: A Survey Using the Theory of Planned Behavior. J. Multidiscip. Healthc. 2020, 13, 1863-1877. [CrossRef] [PubMed]

37. Sánchez-Cañizares, S.M.; Cabeza-Ramírez, L.J.; Muñoz-Fernández, G.; Fuentes-García, F.J. Impact of the Perceived Risk from Covid-19 on Intention to Travel. Curr. Issues Tour. 2021, 24, 970-984. [CrossRef]

38. Long, N.N.; Khoi, B.H. An Empirical Study about the Intention to Hoard Food during COVID-19 Pandemic. Eurasia J. Math. Sci. Technol. Educ. 2020, 16, em1857. [CrossRef]

39. Barnes, S.J.; Diaz, M.; Arnaboldi, M. Understanding Panic Buying during COVID-19: A Text Analytics Approach. Expert Syst. Appl. 2020, 169, 114360. [CrossRef]

40. Degli Esposti, P.; Mortara, A.; Roberti, G. Sharing and Sustainable Consumption in the Era of COVID-19. Sustainability 2021, 13, 1903. [CrossRef]

41. Li, J.; Hallsworth, A.G.; Coca-Stefaniak, J.A. Changing Grocery Shopping Behaviours among Chinese Consumers at the Outset of the COVID-19 Outbreak. Tijdschr. Econ. Soc. Geogr. 2020, 111, 574-583. [CrossRef]

42. Brizi, A.; Biraglia, A. "Do I Have Enough Food?" How Need for Cognitive Closure and Gender Impact Stockpiling and Food Waste during the COVID-19 Pandemic: A Cross-National Study in India and the United States of America. Personal. Individ. Differ. 2021, 168, 110396. [CrossRef]

43. Kitchenham, B.; Pfleeger, S.L. Principles of Survey Research: Part 5: Populations and Samples. ACM SIGSOFT Softw. Eng. Notes 2002, 27, 17-20. [CrossRef]

44. Heckathorn, D.D. Comment: Snowball versus Respondent-Driven Sampling. Sociol. Methodol. 2011, 41, 355-366. [CrossRef] [PubMed]

45. Browne, K. Snowball Sampling: Using Social Networks to Research Non-heterosexual Women. Int. J. Soc. Res. Methodol. 2005, 8 , 47-60. [CrossRef]

46. Druică, E.; Musso, F.; Ianole-Călin, R. Optimism Bias during the Covid-19 Pandemic: Empirical Evidence from Romania and Italy. Games 2020, 11, 39. [CrossRef]

47. Dockery, M.; Bawa, S. Working from Home in the COVID-19 Lockdown. BCEC 2020, 19, 1-5.

48. Baltar, F. Brunet Ignasi Social Research 2.0: Virtual Snowball Sampling Method Using Facebook. Internet Res. 2012, 22, 57-74. [CrossRef] 
49. Rhodes, R.E.; Courneya, K.S. Investigating Multiple Components of Attitude, Subjective Norm, and Perceived Control: An Examination of the Theory of Planned Behaviour in the Exercise Domain. Br. J. Soc. Psychol. 2003, 42, 129-146. [CrossRef] [PubMed]

50. White, K.M.; Smith, J.R.; Terry, D.J.; Greenslade, J.H.; McKimmie, B.M. Social Influence in the Theory of Planned Behaviour: The Role of Descriptive, Injunctive, and in-Group Norms. Br. J. Soc. Psychol. 2009, 48, 135-158. [CrossRef]

51. Ajzen, I. Constructing a TpB Questionnaire: Conceptual and Methodological Considerations. 2002. Available online: http: / / chuang.epage.au.edu.tw / ezfiles/168/1168/attach/20/pta_41176_7688352_57138.pdf (accessed on 15 June 2021).

52. Cialdini, R.B.; Kallgren, C.A.; Reno, R.R. A Focus Theory of Normative Conduct: A Theoretical Refinement and Reevaluation of the Role of Norms in Human Behavior. In Advances in Experimental Social Psychology; Zanna, M.P., Ed.; Academic Press: Cambridge, MA, USA, 1991; Volume 24, pp. 201-234, ISBN 0065-2601.

53. Tajfel, H.; Turner, J. An integrative theory of intergroup conflict. In Intergroup Relations: Essential Readings; Key Readings in Social Psychology; Psychology Press: New York, NY, USA, 2001; pp. 94-109, ISBN 0-86377-678-7.

54. Perkins, H.W. Social Norms and the Prevention of Alcohol Misuse in Collegiate Contexts. J. Stud. Alcohol Suppl. 2002, 14, 164-172. [CrossRef]

55. Hair, J.F., Jr.; Sarstedt, M.; Ringle, C.M.; Gudergan, S.P. Advanced Issues in Partial Least Squares Structural Equation Modeling; SAGE Publications: Thousand Oaks, CA, USA, 2017; ISBN 1-4833-7738-5.

56. Mehmetoglu, M. Partial least squares approach to structural equation modeling for tourism research. In Advances in Hospitality and Leisure; Emerald Group Publishing Limited: Bingley, England, 2012; Volume 8, pp. 43-61. ISBN 1-78052-936-8.

57. Chin, W.W. The partial least squares approach for structural equation modeling. In Modern Methods for Business Research; Methodology for Business and Management; Lawrence Erlbaum Associates Publishers: Mahwah, NJ, USA, 1998 ; pp. $295-336$. ISBN 0-8058-2677-7.

58. Loewenstein, G.F.; Weber, E.U.; Hsee, C.K.; Welch, N. Risk as Feelings. Psychol. Bull. 2001, 127, 267-286. [CrossRef] [PubMed]

59. Fornell, C.; Bookstein, F.L. Two Structural Equation Models: LISREL and PLS Applied to Consumer Exit-Voice Theory. J. Mark. Res. 1982, 19, 440-452. [CrossRef]

60. Fornell, C.; Larcker, D.F. Evaluating Structural Equation Models with Unobservable Variables and Measurement Error. J. Mark. Res. 1981, 18, 39-50. [CrossRef]

61. Druică, E.; Vâlsan, C.; Ianole-Călin, R.; Mihail-Papuc, R.; Munteanu, I. Exploring the Link between Academic Dishonesty and Economic Delinquency: A Partial Least Squares Path Modeling Approach. Mathematics 2019, 7, 1241. [CrossRef]

62. Sijtsma, K. On the Use, the Misuse, and the Very Limited Usefulness of Cronbach's Alpha. Psychometrika 2009, 74, 107. [CrossRef]

63. Farrell, A.M.; Rudd, J.M. Factor Analysis and Discriminant Validity: A Brief Review of Some Practical Issues; ANZMAC: Melbourne, Astralia, 2009.

64. Hu, L.; Bentler, P.M. Cutoff Criteria for Fit Indexes in Covariance Structure Analysis: Conventional Criteria versus New Alternatives. Struct. Equ. Modeling Multidiscip. J. 1999, 6, 1-55. [CrossRef]

65. Cohen, J. Statistical Power Analysis for the Behavioral Sciences, 2nd ed.; Lawrence Erlbaum Associates Publishers: Mahwah, NJ, USA, 1988; ISBN 978-0-8058-0283-2.

66. În Loc de Coronavirus, Foamea Ne va Ucide. Zorii Unei Crize Alimentare Globale. Digi24. 2021. Available online: https://www. digi24.ro/stiri/externe/mapamond/in-loc-de-coronavirus-foamea-ne-va-ucide-zorii-unei-crize-alimentare-globale-1296159 (accessed on 15 June 2021).

67. Arvinte, A. Criza Alimentară Lovește România? evz.ro. 2020. Available online: https:/ / evz.ro/ criza-alimentara-loveste-romaniaministrul-agriculturii-anunt-oficial.html (accessed on 15 June 2021).

68. Montaño, D.E.; Kasprzyk, D. Theory of Reasoned Action, Theory of Planned Behavior, and the Integrated Behavioral Model. Health Behav. Theory Res. Pract. 2015, 70, 231.

69. Zhang, J.; Dawes, S.S. Expectations and Perceptions of Benefits, Barriers, and Success in Public Sector Knowledge Networks. Public Perform. Manag. Rev. 2006, 29, 433-466.

70. Murphy, C.C.; Vernon, S.W.; Diamond, P.M.; Tiro, J.A. Competitive Testing of Health Behavior Theories: How Do Benefits, Barriers, Subjective Norm, and Intention Influence Mammography Behavior? Ann. Behav. Med. 2014, 47, 120-129. [CrossRef] [PubMed]

71. Hamilton, R.; Thompson, D.; Bone, S.; Chaplin, L.N.; Griskevicius, V.; Goldsmith, K.; Hill, R.; John, D.R.; Mittal, C.; O’Guinn, T. The Effects of Scarcity on Consumer Decision Journeys. J. Acad. Mark. Sci. 2019, 47, 532-550. [CrossRef]

72. Zhu, M.; Yang, Y.; Hsee, C.K. The Mere Urgency Effect. J. Consum. Res. 2018, 45, 673-690. [CrossRef]

73. Mitchell, V.-W.; Walsh, G.; Yamin, M. Towards a Conceptual Model of Consumer Confusion. ACR N. Am. Adv. 2005, 32, 143-150.

74. Bruckman, J.C. Overcoming Resistance to Change: Causal Factors, Interventions, and Critical Values. Psychol. Manag. J. 2008, 11, 211-219. [CrossRef]

75. Martin-Neuninger, R.; Ruby, M.B. What Does Food Retail Research Tell Us About the Implications of Coronavirus (COVID-19) for Grocery Purchasing Habits? Front. Psychol. 2020, 11, 1448. [CrossRef] [PubMed]

76. Taylor, S. Understanding and Managing Pandemic-Related Panic Buying. J. Anxiety Disord. 2021, 78, 102364. [CrossRef]

77. Umberson, D.; Montez, J.K. Social Relationships and Health: A Flashpoint for Health Policy. J. Health Soc. Behav. 2010, 51 (Suppl. 1), S54-S66. [CrossRef] 
78. Holt-Lunstad, J.; Smith, T.B.; Layton, J.B. Social Relationships and Mortality Risk: A Meta-Analytic Review. PLoS Med. 2010, 7 , e1000316. [CrossRef] [PubMed]

79. Drury, J. The Role of Social Identity Processes in Mass Emergency Behaviour: An Integrative Review. Eur. Rev. Soc. Psychol. 2018, 29, 38-81. [CrossRef]

80. Askegaard, S.; Madsen, T.K. European Food Cultures: An Exploratory Analysis of Food Related Preferences and Behaviour in European Regions. MAPP Work. Pap. 1995, 26, 1-40.

81. Ianole-Călin, R.; Francioni, B.; Masili, G.; Druică, E.; Goschin, Z. A Cross-Cultural Analysis of How Individualism and Collectivism Impact Collaborative Consumption. Resour. Conserv. Recycl. 2020, 157, 104762. [CrossRef]

82. Billore, S.; Anisimova, T. Panic Buying Research: A Systematic Literature Review and Future Research Agenda. Int. J. Consum. Stud. 2021. [CrossRef]

83. Roman, M.; Plopeanu, A.-P. The Effectiveness of the Emergency ELearning during COVID-19 Pandemic. The Case of Higher Education in Economics in Romania. Int. Rev. Econ. Educ. 2021, 37, 100218. [CrossRef] 